\title{
BESPREKING: NEO-MARXISME
}

Ds. A. N. Helberg: 'n Inleiding tot die bespreking van neomarxisme in die kerklike lewe en ons antwoord daarop:

Vir die doel van ons bespreking is dit goed om eers enkele sake te onderstreep wat in $\mathrm{dr}$. Van Wyk de Vries se voordrag na vore gekom het.

Verder lyk dit sinvol vir 'n vrugbare bespreking om te kyk in hoeverre die kerk self, onbewus, 'n teelaarde geskep of geword het, vir hierdie neo-marxistiese idees. Vanuit hierdie hoek sal ons dan probeer antwoord op die neo-marxistiese aanslag in die kerklike lewe.

1. Sake wat ek graag wil onderstreep in die voordrag is:

1.1. Die identifisering van die koninkryk van God met kerk en wêreld.

1.2. Die aksentuering van die gemeenskap ten koste van die individu. (Die kollektivistiese uitgangspunt).

1.3. Die geringskatting van die kerk as instituut.

1.4. Die opvallende aktivisme.

1.5. Die totale of radikale horisontalisme.

Al hierdie sake tree prominent na vore in die siening van Harvey Cox op die kerk. In sy bekende boek "The secular city" (S.C.M. Press Ltd., Londen) gaan hy in op die verhouding tussen die koninkryk van God en kerk. Volgens hom is die taak van die kerk tans om die moderne mens te konfronteer met 'n nuwe realiteit, nl. die metropolis. God wil dat ons almal saam aan dié „, secular city" sal bou. Die koninkryk van God is in Jesus Christus en van Hom bely ons dat Hy God én mens is. Daarin lê dan opgesluit die saamgaan van goddelike inisiatief en menslike aksie.

In die hele verstedelikingsproses sien ons dieselfde: dit is enersyds 'n sosiale revolusie wat die mens oorval, maar andersyds ook iets wat die moderne mens self tot stand bring.

Die taak van die kerk in hierdie ,secular city" bestaan uit drie dinge:

Kerugma (verkondiging) - maar dié verkondiging sal moet inhou dat die moderne mens werklik die aarde kan beheers, hy is meester oor die wêreld.

Diakonia (diens) - hulp aan dié mense wat in die Amerikaanse stede 'n ellendige bestaan voer.

Koinonia (gemeenskapsvoering) - die ware kerk word nie gekenmerk deur die suiwere Woordverkondiging en sakramentsbediening nie, maar deur 'n nuwe humaniteit, 'n medemenslikheid in die metropool.

In 'n baie interessante artikel in „Elsevier" (16 Oktober 1971) met die titel: „Heeft de kerk nog toekomst”, word die siening van 
'n vyftal teoloë op die kerk gegee. Dieselfde neo-marxistiese tendense tree in sommige van hulle sienings na vore.

Hier is 'n paar van hulle uitsprake:

„Het accent zal echter moeten verschuiven van het instituut naar de mens ..." (Dr. J. van Klinken).

„De zelfstandig geworden christen kan niet meer pro-forma functioneren, hij moet betrokken worden in bezinnend verband, in concreet dienende taken" (Dr. J. van Klinken).

Op die vraag watter kerk nog in die toekoms sal voortbestaan, antwoord prof. C. W. Monnich: „Een kerk waarin de sociale gerechtigheid voorop zal moeten staan".

Die skrywer van die artikel kom dan tot dié slotsom: „Als de kerk een toekomst heeft, zal ze dat hebben als gemeenschap met een gemeenschappelijke oriëntatie ten aanzien van de richting des levens".

2. In hoeverre het die kerk self, onbewus 'n teelaarde geskep of geword vir hierdie idees? In die reeds genoemde artikel word 'n paar dinge genoem wat ons kan beoordeel.

In hoeverre sou dit betrekking hê op die kerk in Suid-Afrika?

2.1. ' $n$ Verouderde organisasiestruktuur is besig om die teoloog en die kerklidmaat van mekaar te vervreem.

2.2. Die kerk het hom te min verset teen dié ontwikkeling wat plaasgevind het, dat die mens die sin en waarheid meer gaan soek het binne die mensdom as daarbuite. Transendensie is besig om plek te maak vir immanensie. Die gevolg? Die koninkryk van God is hierdie wêreld.

2.3. Die kerk het toegelaat dat daar 'n spanning ontstaan tussen die vorme waarin die kerk homself manifesteer en die verwagtingspatroon van die jong mense binne of buite die kerk.

2.4. Die kerk het die dupe geword van 'n pendelbeweging tussen die aksent op persoonlike spiritualiteit (vertikalisme) en die besorgdheid om die wêreld (horisontalisme).

2.5. Die kerk hou te min rekening met die feit dat hy tans in 'n oorgangsfase funksioneer: 'n oorgang van die statiese na die dinamiese, van die substansiële na die funksionele.

3. Wat is ons antwoord op die neo-marxistiese aanslag? (Enkele kritiese opmerkings met inagneming van die verstarring in die kerk wat deur een van die sprekers genoem is.)

3.1. Aktuele Skrifprediking wat die mens werklik aanspreek in sy konkrete situasie, met besondere klem op die versoening tussen God en mens. Die gesag van die Bybel self moet spreek. Is ons prediking nie soms te werklikheidsvreemd en swewend nie?

3.2. Aktivering van die amp van die gelowige. Is daar in die kerk nie te veel van 'n eenrigtingverkeer nie? Is ons nie te gou tevrede as 'n lidmaat maar net twee maal per Sondag kerk toe gaan nie? Funksioneer die amp van die gelowige werklik 
nog na wense en doen die kerk genoeg om dit te aktiveer? Groei die aktivisme nie welig op die bodem van die doodsheid van die amp van die gelowige nie?

3.3. Is daar by ons nie 'n oorbeklemtoning van die kerk as instituut en 'n gevolglike teenreaksie daarteen deur heeltemal daarvan weg te beweeg nie? Het die kerk nie dalk deur 'n oorbeklemtoning van die kerk as instituut inisiatief gesmoor en daartoe bygedra dat die amp van die gelowige nie meer na wense funksioneer nie?

3.4. Die kerk se gerigtheid was en is nog steeds sterk vertikaal. Liefde tot die medemens moet voortvloei uit die liefde tot God. Maar waarom het die horisontale gerigtheid dan nie altyd sterk genoeg na vore getree nie? Waarom het dit nie altyd voortgevloei uit ons vertikale gerigtheid nie? Sou daar dalk iets daarmee skort?

3.5. Weë en middele moet bedink word om die belydenisskrifte weer by vernuwing te laat spreek. Doen ons genoeg in hierdie opsig? 